\title{
Soil Carbon Stocks Vary Across Geomorphic Settings in Australian Temperate Tidal Marsh Ecosystems
}

\author{
Connor Gorham, ${ }^{1 *} \odot$ Paul Lavery, ${ }^{1} \odot$ Jeffrey J. Kelleway, ${ }^{2} \odot$ \\ Cristian Salinas, ${ }^{1} \odot$ and Oscar Serrano ${ }^{1,3}{ }_{\odot}$
}

\begin{abstract}
${ }^{1}$ School of Science, Centre for Marine Ecosystems Research, Edith Cowan University, Joondalup, WA, Australia; ${ }^{2}$ School of Earth, Atmospheric and Life Sciences, University of Wollongong, Wollongong, NSW, Australia; ${ }^{3}$ Biosfera, Associacio d'Edudacio Ambiental, Catalonia, Spain
\end{abstract}

\begin{abstract}
Tidal marshes rank among the ecosystems with the highest capacity to sequester and store organic carbon $\left(\mathrm{C}_{\text {org }}\right)$ on earth. To inform conservation of coastal vegetated ecosystems for climate change mitigation, this study investigated the factors driving variability in carbon storage. We estimated soil $\mathrm{C}_{\text {org }}$ stocks in tidal marshes across temperate Western Australia and assessed differences among geomorphic settings (marine and fluvial deltas, and mid-estuary) and vegetation type (Sarcocornia quinqueflora and Juncus kraussii) linked to soil biogeochemistry. Soil $\mathrm{C}_{\text {org }}$ stocks within fluvial and mid-estuary settings were significantly higher $\left(209 \pm 14\right.$ and $211 \pm 20 \mathrm{Mg} \mathrm{C}_{\text {org }}$ ha $^{-1}$, respectively; $1-\mathrm{m}$-thick soils) than in marine counterparts $\left(156 \pm 12 \mathrm{Mg} \mathrm{C}_{\text {org }} \mathrm{ha}^{-1}\right)$, which can be partially explained by higher preservation of soil $\mathrm{C}_{\text {org }}$ in fluvial and mid-estuary settings rich in fine-grained $(<0.063 \mathrm{~mm})$ sediments $(49 \pm 3 \%$ and $47 \pm 4 \%$, respectively) compared to marine settings
\end{abstract}

Received 17 December 2019; accepted 28 May 2020; published online 24 June 2020

Electronic supplementary material: The online version of this article (https://doi.org/10.1007/s10021-020-00520-9) contains supplementary material, which is available to authorized users.

Author's Contribution CG and OS conceived the ideas and designed the study; CG, OS, CS, PL and JJK collected the data; CG analysed the samples and performed the statistical analyses; OS, PL and JJK contributed to interpreting results; CG wrote the first draft of the manuscript, and all authors reviewed and edited the manuscript.

*Corresponding author; e-mail: c.gorham@ecu.edu.au
$(23 \pm 4 \%)$. Soil $\mathrm{C}_{\text {org }}$ stocks were not significantly different between $S$. quinqueflora and J. kraussii marshes (185 \pm 13 and $202 \pm 13 \mathrm{Mg} \mathrm{C}_{\text {org }}$ ha $^{-1}$, respectively). The higher contribution of tidal marsh plus supratidal vegetation in fluvial $(80 \%)$ and intermediate $(76 \%)$ compared to marine $(57 \%)$ settings further explains differences in soil $\mathrm{C}_{\text {org }}$ stocks. The estimated soil $\mathrm{C}_{\text {org }}$ stocks in temperate Western Australia's tidal marshes (57 Tg C $\mathrm{C}_{\text {org }}$ within $\sim 3000 \mathrm{~km}^{2}$ extent) correspond to about $2 \%$ of worldwide tidal marsh soil $\mathrm{C}_{\mathrm{org}}$ stocks. The results obtained identify global drivers of soil $\mathrm{C}_{\text {org }}$ storage in tidal marshes and can be used to target hot spots for climate change mitigation based on tidal marsh conservation.

Key words: Saltmarsh; Carbon storage; Temperate ecosystems; Habitat characteristics; Blue carbon; Coastal ecosystems; Biogeochemical cycles; Western Australia. 


\section{HighLights}

- Soil organic carbon stocks were 1.3-fold higher in upstream tidal marsh

- Mud content and halophyte contribution enhanced the soil organic carbon stocks

- Temperate Western Australia holds about $2 \%$ of worldwide tidal marsh soil carbon stocks

\section{INTRODUCTION}

Recent emphasis on climate change mitigation has focused attention on the valuation of ecosystems that naturally act as carbon sinks (Ullman and others 2013). Blue carbon ecosystems, such as tidal marshes, mangroves and seagrasses, have been identified as some of the most efficient carbon sinks on earth (McLeod and others 2011). Although terrestrial ecosystems typically reach maximum soil organic carbon $\left(\mathrm{C}_{\text {org }}\right)$ sequestration capacity within decades or centuries, blue carbon ecosystems are capable of accumulating $\mathrm{C}_{\text {org }}$ in their soils over millennia (Nellemann and others 2009; McLeod and others 2011). On a per unit area basis, tidal marshes are one of the most efficient $\mathrm{C}_{\text {org }}$ sinks globally (McLeod and others 2011). However, global estimates of the total soil $\mathrm{C}_{\text {org }}$ inventories in tidal marsh ecosystems remain poorly understood. This can be attributed to a lack of below-ground $\mathrm{C}_{\text {org }}$ data from globally relevant regions and limitations in tidal marsh areal coverage and distribution data (Chmura and others 2003; Duarte and others 2013; Mcowen and others 2017).

Tidal marsh ecosystems occur on all continents except Antarctica and though they persist across all climatic regions, they are most prevalent in temperate zones (Mcowen and others 2017). Tidal marshes inhabit a wide variety of geomorphic and depositional environments and can exhibit significant variability in soil $\mathrm{C}_{\text {org }}$ stocks across multiple spatial and temporal scales. At the global scale, variability of tidal marsh soil $\mathrm{C}_{\text {org }}$ stocks is primarily driven by historic rises in sea-level, which controlled vertical accretion of mineral and organic materials (Rogers and others 2019). In addition, estimates of tidal marsh soil $C_{\text {org }}$ storage capacity at continental or regional scales can be highly variable (up to 68-fold; Macreadie and others 2017), which points to the importance of local environmental drivers influencing soil $\mathrm{C}_{\text {org }}$ storage.

Variability in soil $\mathrm{C}_{\text {org }}$ stocks at the regional scale has been associated with differences in climatic and physical variables (for example, temperature, salinity, precipitation, sediment type, elevation, periodicity and intensity of inundation; Christiansen and others 2000; Chmura and others 2003; Butzeck and others 2014; Baustian and others 2017). For example, cooler climates and greater rainfall, characteristic of temperate regions, minimise salinity-induced stress and enhance growth rates and survivorship of tidal marsh plants, contributing to autochthonous $\mathrm{C}_{\text {org }}$ inputs into the soil (Adam 1990; Saintilan 2009). Although plant community structure, topography and resulting inundation regimes likely influence $\mathrm{C}_{\text {org }}$ availability in tidal marsh habitats, variability at the withinestuary spatial scale is largely attributed to variation in geomorphic settings and their influence on physical and physico-chemical characteristics of tidal marsh habitats (Kelleway and others 2016; Baustian and others 2017; Alongi 2018; van Ardenne and others 2018). Differences in fluvial and marine influence on tidal marsh can alter the supply of nutrients, salinity and sediment availability (Roy and others 2001; Saintilan and others 2009; Kelleway and others 2016). These factors can impact rates of tidal marsh primary production and decomposition of plant biomass and other organic matter within systems (Saintilan and others 2013), and thereby soil $\mathrm{C}_{\text {org }}$ storage. In estuaries, the depositional characteristics of tidal marsh habitats are often associated with their geomorphic setting, including marine flood tidal deltas, mid-estuarine tidal flats, fluvial deltas and riverine habitats (Roy and others 2001; Saintilan and others 2009; Kelleway and others 2016). Previous studies have shown that tidal marsh habitats situated near fluvial deltas can store up to twofold larger soil $\mathrm{C}_{\text {org }}$ stocks than marine-dominated counterparts (Kelleway and others 2016; Macreadie and others 2017).

Furthermore, differences in geomorphic setting (topography and hydrology) influence soil characteristics (for example, sediment grain size and mineralogy), suspended sediment supply, allochthonous carbon inputs and the production and/or deposition of biogenic carbonates in tidal marsh habitats, which contribute to spatial variability in soil $\mathrm{C}_{\text {org }}$ at the within-estuary scale (Kelleway and others 2016; Macreadie and others 2017). For example, an abundance of fine-grained sediments, characteristic of fluvial-influenced tidal marsh, are likely to limit oxygen exchange and redox potential within soils, thereby limiting organic matter remineralisation rates and enhancing soil $\mathrm{C}_{\text {org }}$ preservation (Hedges and Keil 1995).

Other potential drivers of within-site variability of $\mathrm{C}_{\text {org }}$ stocks are spatial patterns in vegetation, 
historic shifts of habitat type (for example, the presence of mangrove soils below contemporary tidal marsh), and the elevation of collected samples from within a site (low, mid and upper marshland; Kelleway and others 2017b; van Ardenne and others 2018). However, factors influencing soil $\mathrm{C}_{\text {org }}$ in tidal marshes remain understudied when compared to those of mangrove and seagrass habitats (Donato and others 2011; Fourqurean and others 2012a; Alongi and others 2016; Serrano and others 2016; Mazarrasa and others 2018; Rovai and others 2018). To allow spatial modelling of regional or global soil $\mathrm{C}_{\text {org }}$ stocks from limited data sets, there is a need for improved habitat distribution data and to better understand the biophysical conditions which control soil $\mathrm{C}_{\text {org }}$ variability in tidal marshes at each spatial scale (Kelleway and others 2016).

Australia contains $5-11 \%$ of the global blue carbon stocks, spread over a wide range of climatic and geomorphic regimes, including up to $35 \%$ of the global tidal marsh soil $\mathrm{C}_{\text {org }}$ stock (Serrano and others 2019). The Western Australia (WA) coastline spans approximately $21,000 \mathrm{~km}$ (about onethird of the Australian coastline; Bucher and Saenger 1991; Geoscience Australia. 2004), encompassing about $22 \%$ of mapped tidal marsh extent in Australia and about $5 \%$ of total worldwide tidal marsh extent (Bucher and Saenger 1991; Mcowen and others 2017; Serrano and others 2019). Tidal marshes within southern WA differ from the more intensely studied temperate tidal marshes of eastern Australia in that they occur along a microtidal coast almost completely devoid of mangroves and subject to strongly seasonal (Mediterranean) climatic conditions (Brearley 2006). Further, owing to the persistent and high wave energy regime of the temperate south-west coastline, the estuaries within this region are collectively wave-dominated barrier estuaries with tidal marsh distributed across multiple geomorphic settings (for example, marine flood tidal deltas and fluvial deltas; Hodgkin and Hesp 1998), presenting the opportunity for a robust comparison of withinestuary variability in soil $\mathrm{C}_{\text {org }}$ stocks.

Previous studies found that soil $\mathrm{C}_{\text {org }}$ stocks in WA tidal marsh ecosystems were up to twofold lower compared to other temperate regions within Australia and worldwide (Chmura and others 2003; Zhang and others 2008; Holmquist and others 2018; Macreadie and others 2017; Serrano and others 2019), including those with similar relative sea-level histories over the Holocene (Rogers and others 2019). However, the WA estimates were based on a limited data set comprising only 10 cores from four tidal marsh ecosystems. The paucity of soil $\mathrm{C}_{\text {org }}$ stock estimates for tidal marsh in the western third of Australia has been recognised as a key limitation in the most comprehensive assessment of blue carbon resources in the country (Serrano and others 2019).

The primary goal of this study was to provide robust estimates of blue carbon stocks for temperate Australian tidal marshes which occur in a highly seasonal, Mediterranean climate zone, and have variable levels of connectivity to the ocean. To this aim, we quantified soil $\mathrm{C}_{\text {org }}$ stocks across temperate WA tidal marshes and assessed potential factors (that is, climate and habitat characteristics) driving carbon storage in tidal marshes. We hypothesise that soil $\mathrm{C}_{\text {org }}$ stocks in temperate WA tidal marshes would be below national and global estimates (as per pre-existing regional estimates). Furthermore, we expected that soil $\mathrm{C}_{\text {org }}$ stocks would be significantly higher in upper estuary locations compared to those situated in seaward locations.

\section{Materials AND Methods}

\section{Study Setting and Experimental Design}

The mean annual rainfall and temperature of WA's temperate region are $824 \mathrm{~mm}$ (dominated by winter rain and dry summers) and $15{ }^{\circ} \mathrm{C}$, respectively (Department of the Environment 2015). The variability of localised rainfall across the temperate coastline is high, with the south coast of WA varying from $450 \mathrm{~mm}$ to $1400 \mathrm{~mm}$ of precipitation as you move from east to west (Hodgkin and Hesp 1998).

Ten estuaries were sampled along the temperate coast of WA, from Perth to Esperance (Figure 1). The sampled estuaries were all wave-dominated barrier estuaries fronted by sandy barrier islands and/or spits. Each estuary maintained either permanently open or intermittently open entrances to the ocean, with some remaining closed for decades at a time (Table 1). Estuarine evolution in WA was greatly influenced by the enhanced sedimentation yields during the Holocene marine transgression (8000 to 4000 years before present), with midHolocene shell deposits previously identified in six of the estuaries sampled in this study (Hodgkin and Hesp 1998). Each of the sampled estuaries exhibits relatively low tidal energy, with a microtidal (0.4 m) range (Hodgkin and Hesp 1998; Ryan and others 2003). Instead, wave energy near the barrier entrance and river inflow in upstream areas are the main contributors of energy, though these inputs are largely dissipated towards the broad central 


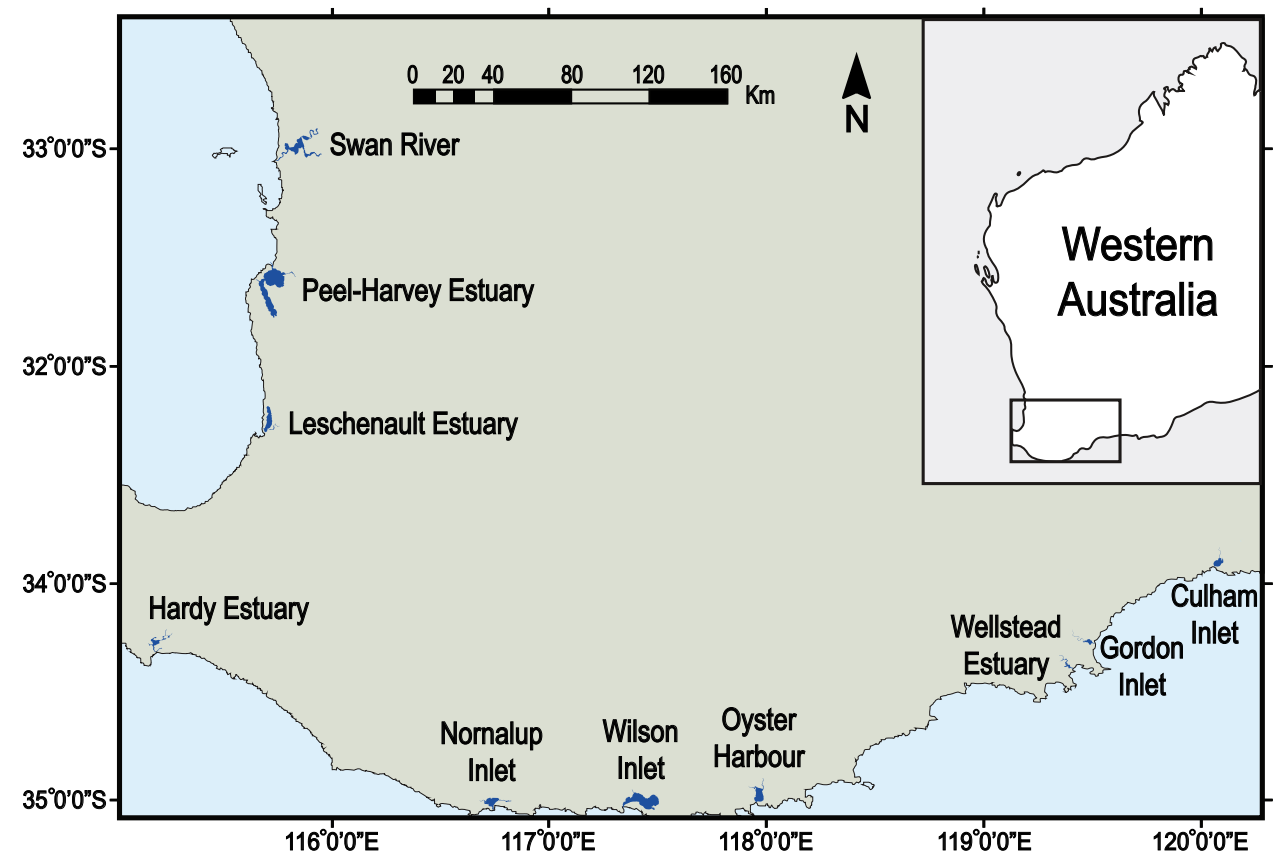

Figure 1. Location of the ten estuaries sampled along the temperate southwest coastline of Western Australia. Dark blue areas along the coastline represent the position and size of each estuary sampled.

basin of each system (Heap and others 2001; Ryan and others 2003).

Tidal marsh ecosystems within this region are comprised of two main vegetative communities: ecosystems formed by low-lying succulent species, dominated by Sarcocornia quinqueflora (Ung.-Sternb.) A.J.Scott; and ecosystems formed by taller rush species, dominated by Juncus kraussii Hochst. The variability in tidal marsh soil $\mathrm{C}_{\text {org }}$ stocks among estuaries was assessed by sampling soil cores in three geomorphic settings within each estuary: marine flood tidal deltas, tidal flats located midestuary and upstream areas subject to fluvial influence (hereafter referred to as 'marine', 'intermediate', and 'fluvial' settings, respectively). In each geomorphic setting, three soil cores were sampled, one core at each of three points along a transect that ran perpendicular to the shoreline: water's edge, middle of the tidal marsh and at the fringing vegetation surrounding the tidal marsh (Figure S3). Within an estuary, sampling was conducted consistently in the same dominant vegetative community (that is, either $S$. quinqueflora or J. kraussii). Owing to the geomorphological characteristics of each estuary and the distribution of plant communities, it was not always possible to sample all geomorphic settings within each estuary, which resulted in an unbalanced design (Table 1).

\section{Soil Sampling}

Soil sampling was carried out by manually hammering PVC pipes $(7.5 \mathrm{~cm}$ inner diameter and $1.5 \mathrm{~m}$ long). A total of 81 cores were sampled among the 10 estuaries studied. Two types of PVC corers were used. 'Whole cores' consisting of entire PVC pipes were used to sample the middle of the tidal marsh across all sites. 'Port cores' consisting of PVC pipes with pre-drilled holes $(3 \mathrm{~cm}$ in diameter) situated at $15 \mathrm{~cm}$ depth intervals along the sidewall of the pipe were used to sample near the water's edge and the landward fringing vegetation. Distances between cores were dependent on the width of the tidal marsh being sampled, ranging between 10 and $50 \mathrm{~m}$. Linear downcore soil compaction was assumed throughout coring and was recorded by measuring the difference in surface soil elevation inside and outside the core (Glew and others 2005). In some operations, the compression of a core was very high $(>40 \%)$, which was assumed to be linked to either the nail effect or extreme compaction of unconsolidated fine sediments. In these few such cases, we repeated the coring operation in a nearby location and discarded nail effects by measuring distances inside and outside of a corer at multiple occasions during coring. Furthermore, we successfully diminished compaction by hammering softly and rotating the corer more often. As a result of this approach, the mean compaction of all cores 
Table 1. Estuary and Study Site Information for the Tidal Marsh Habitats Sampled in Temperate Western Australia

\begin{tabular}{|c|c|c|c|c|c|c|}
\hline Estuary & $\begin{array}{l}\text { Entrance } \\
\text { condition }\end{array}$ & $\begin{array}{l}\text { Dominant } \\
\text { Species }\end{array}$ & $\begin{array}{l}\text { Geomorphic } \\
\text { Setting }\end{array}$ & Latitude & Longitude & $\begin{array}{l}\text { Hydrological Distance } \\
\text { from Ocean }(\mathrm{km})\end{array}$ \\
\hline \multirow[t]{2}{*}{ Swan-Canning River } & \multirow[t]{2}{*}{ Open } & \multirow[t]{2}{*}{ J. kraussii } & Intermediate & -32.0260 & 115.8127 & 13.6 \\
\hline & & & Fluvial & -32.0286 & 115.9009 & 24.1 \\
\hline \multirow[t]{3}{*}{ Peel-Harvey Estuary } & \multirow[t]{3}{*}{ Open } & \multirow[t]{3}{*}{ S. quinqueflora } & Marine & -32.5434 & 115.7202 & 2.8 \\
\hline & & & Intermediate & -32.6427 & 115.6469 & 5.8 \\
\hline & & & Fluvial & -32.5519 & 115.7586 & 12.5 \\
\hline \multirow{3}{*}{ Leschenault Estuary } & \multirow[t]{3}{*}{ Open } & \multirow{3}{*}{ S. quinqueflora } & Marine & -33.3002 & 115.6795 & 1.3 \\
\hline & & & Intermediate & -33.3019 & 115.6904 & 2.0 \\
\hline & & & Fluvial & -33.3204 & 115.6794 & 2.3 \\
\hline \multirow[t]{3}{*}{ Hardy Inlet } & \multirow[t]{3}{*}{ Open } & \multirow[t]{3}{*}{ J. kraussii } & Marine & -34.3179 & 115.1764 & 1.5 \\
\hline & & & Intermediate & -34.2876 & 115.1618 & 4.8 \\
\hline & & & Fluvial & -34.2613 & 115.1990 & 9.5 \\
\hline \multirow[t]{3}{*}{ Walpole-Nornalup Inlet } & \multirow[t]{3}{*}{ Open } & \multirow{3}{*}{ J. kraussii } & Marine & -35.0231 & 116.7363 & 1.3 \\
\hline & & & Intermediate & -34.9983 & 116.7106 & 4.7 \\
\hline & & & Fluvial & -35.0000 & 116.8118 & 10.0 \\
\hline \multirow[t]{3}{*}{ Wilson Inlet } & \multirow[t]{3}{*}{ Intermittent } & \multirow[t]{3}{*}{ J. kraussii } & Marine & -35.0245 & 117.3267 & 0.7 \\
\hline & & & Intermediate & -35.0085 & 117.3287 & 2.1 \\
\hline & & & Fluvial & -34.9988 & 117.4789 & 15.3 \\
\hline \multirow[t]{3}{*}{ Oyster Harbour } & \multirow[t]{3}{*}{ Open } & \multirow[t]{3}{*}{ J. kraussii } & Marine & -34.9920 & 117.9413 & 1.1 \\
\hline & & & Intermediate & -34.9623 & 117.9750 & 4.8 \\
\hline & & & Fluvial & -34.9385 & 117.9796 & 7.4 \\
\hline \multirow[t]{2}{*}{ Wellstead Estuary } & \multirow[t]{2}{*}{ Intermittent } & \multirow[t]{2}{*}{ S. quinqueflora } & Intermediate & -34.3853 & 119.3645 & 3.3 \\
\hline & & & Fluvial & -34.3649 & 119.3656 & 5.2 \\
\hline \multirow[t]{3}{*}{ Gordon Inlet } & \multirow[t]{3}{*}{ Intermittent } & \multirow[t]{3}{*}{ S. quinqueflora } & Marine & -34.2841 & 119.4926 & 1.3 \\
\hline & & & Intermediate & -34.2836 & 119.4736 & 2.9 \\
\hline & & & Fluvial & -34.2824 & 119.4527 & 5.3 \\
\hline \multirow[t]{2}{*}{ Culham Inlet } & \multirow[t]{2}{*}{ Intermittent } & \multirow[t]{2}{*}{ S. quinqueflora } & Marine & -33.9235 & 120.0542 & 1.0 \\
\hline & & & Fluvial & -33.8869 & 120.0917 & 6.2 \\
\hline
\end{tabular}

Hydrological distance $=$ distance between tidal marsh location and open ocean following the most direct hydrological route (assuming an open estuary mouth).

ranged from 0 to $36 \%$ (mean \pm SE; $12 \pm 1 \%$ ), which is typical of unconsolidated wetland soils using similar coring methods (Kelleway and others 2016).

The port cores were subsampled in the field by inserting a $60-\mathrm{mL}$ modified syringe into each port, and the total volume of soils subsampled was recorded (Fourqurean and others 2012b). Samples of macrophytes and surrounding vegetation (genera: Juncus, Sarcocornia, Tecticornia, Sporobolus, Samolus, Suaeda, Eucalyptus and Melaleuca) were collected where present at the study sites as potential endmembers for source attribution using stable isotope approaches. Macrophyte and surrounding vegetation samples comprised fresh stem and leaf biomass. All samples were refrigerated at $4{ }^{\circ} \mathrm{C}$ before laboratory analyses.

\section{Analytical Procedures}

In the laboratory, whole cores were opened lengthwise and soils were sectioned at $1 \mathrm{~cm}$ inter- vals for the top $20 \mathrm{~cm}$ and at $5 \mathrm{~cm}$ intervals for the remainder $(>20 \mathrm{~cm})$. This work focused on $\mathrm{C}_{\text {org }}$ located below-ground because much of the aboveground plant material is not sequestered in the long term, and, most importantly, because the highest proportion of the carbon stock is in the sedimentary, below-ground pool (Serrano and others 2019). All soil samples, including those from the port cores, were dried at $60{ }^{\circ} \mathrm{C}$ until constant weight to estimate dry bulk density (DBD; g DW $\mathrm{cm}^{-3}$ ). The bulk samples were split into subsamples by quartering. Subsamples were individually homogenised and ground to a fine powder for biogeochemical analyses. Approximately $4 \mathrm{~g}$ powder of all subsamples was combusted at $550{ }^{\circ} \mathrm{C}$ to estimate the proportionate loss of organic matter following the methods reported by Heiri and others (2001).

A subset of samples from whole cores ('compressed' sections 0-1 cm, 3-4 cm, 6-7 cm, 9$10 \mathrm{~cm}, 14-15 \mathrm{~cm}, 19-20 \mathrm{~cm}, 25-30 \mathrm{~cm}, 40-45 \mathrm{~cm}$, 
55-60 cm, 75-80 cm) were analysed for sediment grain size, $\mathrm{CaCO}_{3}, \mathrm{C}_{\text {org }}$ and stable isotope composition $\left(\delta^{13} \mathrm{C}\right.$ and $\left.\delta^{15} \mathrm{~N}\right)$. Sediment grain size was measured with a Coulter LS230 laser diffraction particle analyser at the University of Barcelona (Spain), after organic matter was digested with $10 \% \mathrm{H}_{2} \mathrm{O}_{2}$. The grain size data were classified in the following fractions: $<0.063 \mathrm{~mm}$ (silt and clay), $>0.063<0.5 \mathrm{~mm}$ (fine and medium sands), $>0.5<2 \mathrm{~mm}$ (coarse sands) and $>2$ $\mathrm{mm}$ (gravel). Statistical methods focused primarily on the silt and clay sediment fraction as previous research has identified fine-grained sediments to be correlated with enhanced sequestration and preservation of soil $\mathrm{C}_{\text {org }}$ (Kelleway and others 2017a).

Prior to $\mathrm{C}_{\text {org }}$ and $\mathrm{CaCO}_{3}$ analyses, powdered soils underwent the 'Champagne test' (Schlacher and Connolly 2014) to determine the presence of inorganic carbon $\left(\mathrm{C}_{\text {inorg }}\right)$. From 266 samples, only 76 bubbled when acidified with $1 \mathrm{M} 10 \% \mathrm{HCl}$. Where $\mathrm{C}_{\text {inorg }}$ was identified, about $1 \mathrm{~g}$ of powdered sample was acidified with $10 \% \mathrm{HCl}$ in a pressure calcimeter to estimate $\% \mathrm{CaCO}_{3}$ content (Horváth and others 2005). To ensure accuracy of the visual Champagne test, a subset of samples $(\sim 33 \%)$ were acidified in the pressure calcimeter to confirm that $\mathrm{CaCO}_{3}$ was absent in these samples. Pure $\mathrm{CaCO}_{3}$ was analysed together with the samples to obtain a calibration curve (that is, linear regression) to estimate soil $\mathrm{C}_{\text {inorg }}$ content.

The $\mathrm{C}_{\text {org }}(\%)$ and stable isotope composition $\left(\delta^{13} \mathrm{C}\right.$ and $\left.\delta^{15} \mathrm{~N}\right)$ of soil organic matter and macrophyte samples were analysed through isotope ratio mass spectrometry (IRMS) at the University of Hawaii's Hilo analytical laboratory. All $\mathrm{C}_{\text {inorg }}$-free soil and macrophyte samples were encapsulated in tin capsules for analysis, while soil samples containing $\mathrm{C}_{\text {inorg }}$ were analysed in duplicate after $4 \%$ $\mathrm{HCl}$ acidification treatment in silver capsules to remove $C_{\text {inorg }}$ (Kennedy and others 2005). The content of $\mathrm{C}_{\text {org }}$ was calculated for the bulk (preacidified) samples. The acidification methods used to remove $\mathrm{CaCO}_{3}$ prior to $\mathrm{C}_{\text {org }}$ analysis have been shown to result in an underestimation of $\mathrm{C}_{\text {org }}$ content, compared to the more reliable estimates of $\mathrm{C}_{\text {org }}$ content in non-acidified and $\mathrm{CaCO}_{3}$-free soil samples (Brodie and others 2011). The different analytical procedures conducted in our study could mask the differences in $\mathrm{C}_{\text {org }}$ storage observed between settings. Isotope ratios are expressed as $\delta$ values in parts per thousand $(\%)$ relative to the Vienna PeeDee Belemnite standard $\left(\delta^{13} \mathrm{C}\right)$ and atmospheric $\mathrm{N}_{2}$ standard $\left(\delta^{15} \mathrm{~N}\right)$. Replicate assays and standards indicated measurement errors of
$0.01 \%$ for $\mathrm{C}_{\text {org }}$ content and $0.2 \%$ for $\delta^{13} \mathrm{C}$ and $\delta^{15} \mathrm{~N}$. The $\delta^{13} \mathrm{C}$ values of bulk soil organic matter obtained in this study (that is, in acid- and non-acidtreated samples) reassure that $\mathrm{CaCO}_{3}$ was not present prior to $\mathrm{C}_{\text {org }}$ analyses; otherwise, little amounts of $\mathrm{CaCO}_{3}$ would have resulted in shifting $\delta^{13} \mathrm{C}$ values towards $0 \%$ (Komada and others 2008). Rather, the range of $\delta^{13} \mathrm{C}$ values identified in this manuscript are representative of what would be expected in temperate tidal marsh soils (ranging from -30 to $-12 \%$; Peterson 1999). Although the soil cores sampled in this study were not dated, available sedimentology records from WA's temperate tidal marshes have identified quartz and carbonate sands, Holocene in age, to occur from $\sim 30 \mathrm{~cm}$ depth (Semeniuk 2000). This suggests that the 1-m-thick soil deposits studied here likely include sediments deposited over the last about 4000 years.

\section{Numerical Procedures}

A linear regression between $\% \mathrm{C}_{\text {org }}$ and \%LOI was used to estimate $\% \mathrm{C}_{\text {org }}$ for subsamples that were not analysed via IRMS (Fourqurean and others 2012a; Figure S1). Soil $\mathrm{C}_{\text {org }}$ stocks estimated from the 81 cores were standardized to $1-m$-thick soil deposits to allow comparisons with previous studies, by extrapolating linearly consistent $\mathrm{C}_{\text {org }}$ values (cumulative $\mathrm{C}_{\text {org }} \mathrm{Mg} \mathrm{ha}^{-1}$ ) with depth (Arias-Ortiz and others 2018). To validate this extrapolation approach, all cores with at least 1-m-thick soil deposits were extrapolated from $60 \mathrm{~cm}$ (shortest length of soil sampled across all sites) to $1 \mathrm{~m}$ following the procedures described above (Figure S2). Total estimates of soil $\mathrm{C}_{\text {org }}$ stocks in temperate WA were calculated by multiplying the mean soil $\mathrm{C}_{\text {org }}$ stock $\left(\mathrm{Mg} \mathrm{C}_{\text {org }}\right.$ ha $\left.^{-1}\right)$ by the total tidal marsh extent in WA $\left(2965 \mathrm{~km}^{2}\right.$; Bucher and Saenger 1991) following the methodology used in Macreadie and others (2017).

To assess differences in tidal marsh soil Corg stocks, \%Corg, DBD, silt and clay contents, $\delta 13 \mathrm{C}$ values and $\mathrm{CaCO}_{3}$ contents (independent variables) among geomorphic settings (dependent variable; marine, intermediate and fluvial), univariate permutational analyses of variance (PERMANOVA) were run in Primer 7, using Euclidean distance to produce Fisher's traditional univariate F statistic (Anderson and others, 2008). Differences in tidal marsh soil $\mathrm{C}_{\text {org }}$ stocks were also analysed between vegetation type (J. kraussii and S. quinqueflora), estuary entrance structure (permanently open and intermittently open) and core transect position (water's edge, middle of tidal marsh and 
fringing vegetation). PERMDISP was used to test for homogeneity of multivariate dispersions. Where this assumption was not met, square root transformations were applied. Where homogeneity could not be achieved, variables were interpreted with an increased confidence interval $(P<0.01)$. A principle component analysis (PCA) was also run in Primer 7 to visualise trends between soil $\% \mathrm{C}_{\text {org }}$ content, DBD, silt and clay content, $\delta^{13} \mathrm{C}$ values and $\mathrm{CaCO}_{3}$ content among geomorphic settings. All data were standardised using z-scores prior to PCA analysis.

Two-isotope, two-source mixing models were run in $\mathrm{R}$ to assess the proportional contribution of source material in temperate WA tidal marsh soils. Mixing models were run using simmr and rjags packages (Parnell and others 2013; Parnell 2019). The isotopes used in this model were $\delta^{13} \mathrm{C}$ and $\delta^{15} \mathrm{~N}$, and the two-source end-members were broadly classified as 'Depleted in ${ }^{13} \mathrm{C}^{\prime}$ and 'Enriched in ${ }^{13} \mathrm{C}^{\prime}$. This broad classification distinguished partially autochthonous organic vegetation (tidal marsh halophytes plus supratidal vegetation) as 'Depleted in ${ }^{13} \mathrm{C}^{\prime}$ and allochthonous vegetation (seagrass, marine seston and macroalgae) as 'Enriched in ${ }^{13} \mathrm{C}^{\prime}$. The reference isotopic signatures (mean \pm SD; Table 2) used in this model comprised weighted mean $\delta^{13} \mathrm{C}$ and $\delta^{15} \mathrm{~N}$ values from this study and published values representative of temperate WA obtained from Smit and others (2005) and Svensson and others (2007; Table S2). Four mixing models were run in total; the first was a broad examination of the total proportional contribution of source material in all temperate WA tidal marsh soils. The remaining three models were structured to explore the differences in source material contribution relative to geomorphic setting (marine, intermediate and fluvial): the first encompassing all tidal marsh, the second $S$. quinqueflora-dominated tidal marsh and the third $J$. kraussii-dominated tidal marsh.

\section{RESUlts}

Across all tidal marsh habitats studied, the $\mathrm{C}_{\text {org }}$ stocks in 1-m-thick soils ranged from 71 to $427 \mathrm{Mg}$ $\mathrm{C}_{\text {org }} \mathrm{ha}^{-1}\left(\right.$ mean $\left.\pm \mathrm{SE} ; 194 \pm 9 \mathrm{Mg} \mathrm{C}_{\text {org }} \mathrm{ha}^{-1}\right)$, with mean $\mathrm{C}_{\text {org }}$ concentration of $5.3 \pm 0.2 \%$ and $24.6 \pm 0.7 \mathrm{mg} \mathrm{C}_{\text {org }} \mathrm{cm}^{-3}$. On average, soil organic matter contained $48.7 \pm 0.6 \% \mathrm{C}_{\text {org }}$. The correlations between $\% \mathrm{C}_{\text {org }}$ and $\% \mathrm{LOI}$ in $1 \mathrm{~m}$ soil profiles $\left(\mathrm{R}^{2}=0.96\right.$; Figure $\left.\mathrm{S} 1\right)$ and between cumulative soil $\mathrm{C}_{\text {org }}$ stocks extrapolated to $1 \mathrm{~m}$ and $\mathrm{C}_{\text {org }}$ stocks measured to $1 \mathrm{~m}\left(\mathrm{R}^{2}=0.92\right)$ were high (Figure S2). The $\delta^{13} \mathrm{C}$ values in all cores averaged $-24 \pm 0.2 \%$ and ranged from -30 to $-12 \%$. The mixing model applied to all cores identified that organic matter sources depleted in ${ }^{13} \mathrm{C}$ were prevalent within the soil $\mathrm{C}_{\text {org }}$ pool in tidal marsh soils in temperate WA $(72 \%)$, compared to sources enriched in ${ }^{13} \mathrm{C}$ (28\%; Table 2$)$.

Overall, the $\mathrm{C}_{\text {org }}$ stocks in 1-m-thick tidal marsh soils were significantly lower in marine settings $\left(156 \pm 12 \mathrm{Mg} \mathrm{C}_{\text {org }} \mathrm{ha}^{-1}\right)$ than those in fluvial or intermediate settings $(209 \pm 14$ and $211 \pm 20 \mathrm{Mg}$ $\mathrm{C}_{\text {org }} \mathrm{ha}^{-1}$, respectively; $P<0.05$; Figure $2 \mathrm{C}$ ). This trend was consistent among all estuaries, with the exception of Culham Inlet that had higher stocks in marine $\left(187 \pm 50 \mathrm{Mg} \mathrm{C}_{\text {org }} \mathrm{ha}^{-1}\right)$ than in fluvial settings (129 $\pm 5 \mathrm{Mg} \mathrm{C}_{\text {org }} \mathrm{ha}^{-1}$ ) and at Hardy Inlet (higher stocks in intermediate settings, $392 \pm 28 \mathrm{Mg} \mathrm{C}_{\text {org }} \mathrm{ha}^{-1}$, than in fluvial and marine settings, $209 \pm 31$ and $222 \pm 17 \mathrm{Mg} \mathrm{C}$ org ha ha $^{-1}$, respectively; Table $\mathrm{S} 1$ ).

Similarly, the biogeochemical characteristics $\left(\% \mathrm{C}_{\text {org }}\right.$ content, $\mathrm{DBD}, \mathrm{CaCO}_{3}$ content, silt and clay content, and $\delta^{13} \mathrm{C}$ composition) in the top meter of tidal marsh soils significantly differed between marine and those in fluvial and intermediate tidal marsh habitats $(P<0.01$, Figure 2$)$. The mean $\mathrm{C}_{\text {org }}$ concentration was lower in marine tidal marsh $\left(2.3 \pm 0.2 \% \mathrm{C}_{\text {org }}\right.$ and $\left.19 \pm 0.6 \mathrm{mg} \mathrm{C}_{\text {org }} \mathrm{cm}^{-3}\right)$ than in fluvial $\left(7.1 \pm 0.4 \% \mathrm{C}_{\text {org }}\right.$ and $26.8 \pm 0.7 \mathrm{mg} \mathrm{C} \mathrm{C}_{\text {org }}$ $\left.\mathrm{cm}^{-3}\right)$ and intermediate tidal marsh $(6.2 \pm 0.4 \%$

Table 2. Isotopic Reference Signatures (mean \pm SD) of Source End-members Used for Calculations, Compiled from Isotopic Values Measured in This Study and Obtained from Smit and others (2005) and Svensson and others (2007)

\begin{tabular}{llll}
\hline Source & \multicolumn{2}{l}{ Reference signatures } & Contribution (\%) \\
\cline { 2 - 3 } & $\delta^{13} \mathrm{C}$ & $\delta^{15} \mathrm{~N}$ & \\
\hline Enriched in ${ }^{13} \mathrm{C}$ & $-15.4 \pm 4.6$ & $4.5 \pm 3.7$ & $27.6(24.1-28.9)$ \\
Depleted in ${ }^{13} \mathrm{C}$ & $-26.6 \pm 1.5$ & $6.7 \pm 3.1$ & $72.4(68.4-75.9)$
\end{tabular}

Contribution reflects the proportional median input (\%) of organic source material in temperate Western Australia's tidal marsh soils as analysed in all cores. Values in parentheses represent the 2.5 and 97.5 confidence percentiles. 


\section{A}

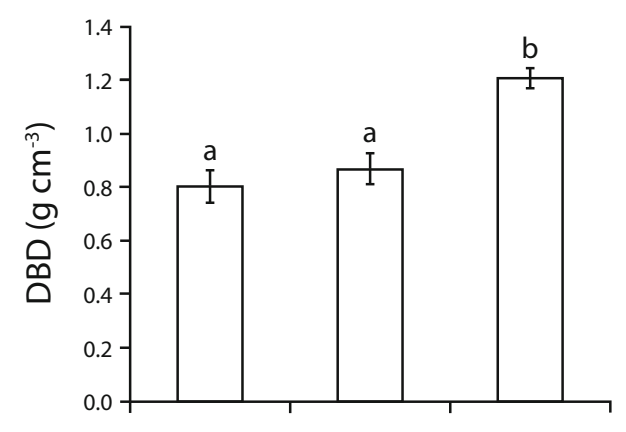

C

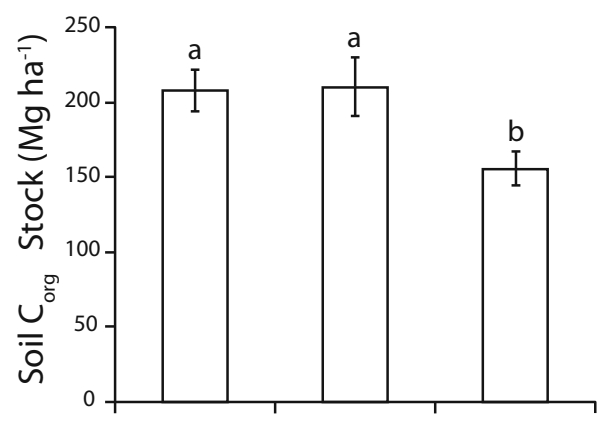

E

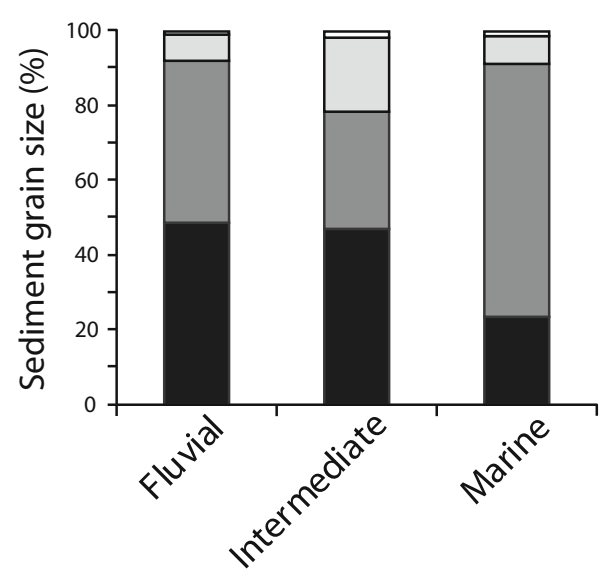

Silt and Clay $(<0.063 \mathrm{~mm})$
B

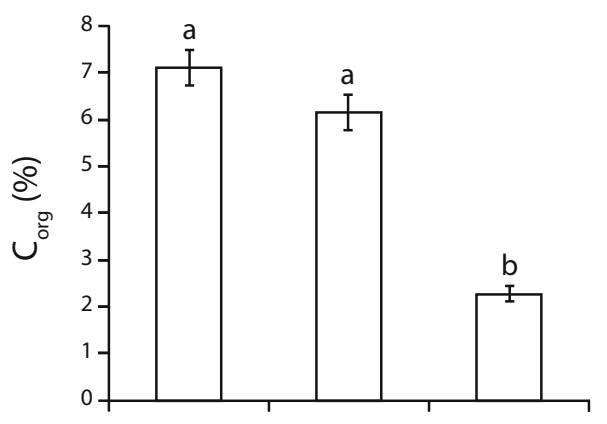

D

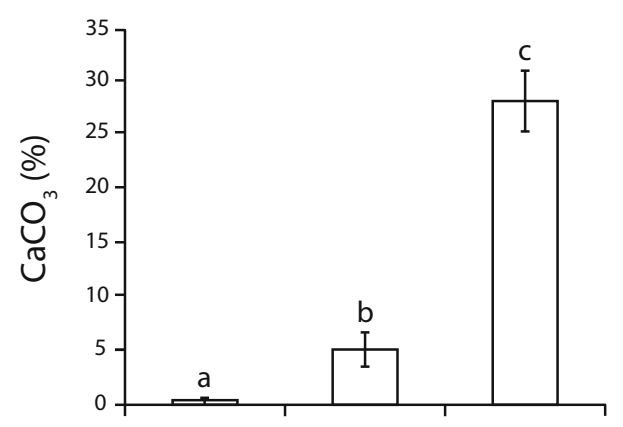

$\mathbf{F}$

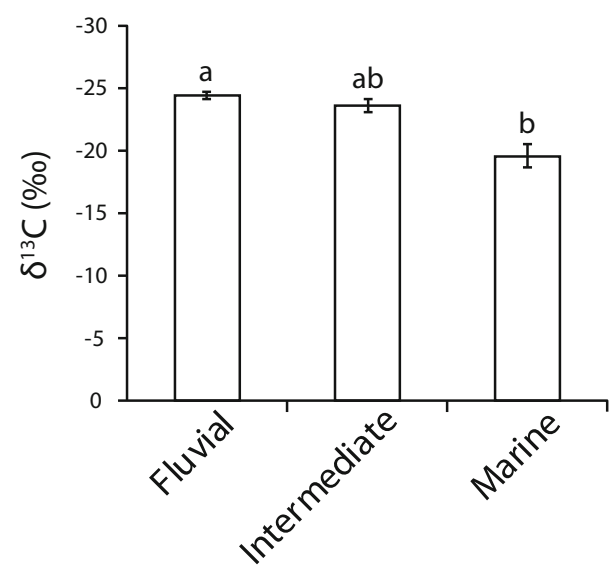

Coarse sands $(>0.5<2.0 \mathrm{~mm})$

Fine and medium sands $(>0.063<0.5 \mathrm{~mm}) \square$ Gravel $(>2.0 \mathrm{~mm})$

Figure 2. Mean ( $\pm \mathrm{SE}$ ) soil organic carbon stocks $\left(\mathrm{Mg} \mathrm{ha}^{-1}\right.$ in $1-\mathrm{m}$-thick soils) (A); soil organic carbon content (\%) (B); dry bulk density (DBD; $\mathrm{g} \mathrm{cm}^{-3}$ ) $\quad(\mathrm{C}) ; \mathrm{CaCO}_{3} \quad(\%) \quad(\mathrm{D}) ; \quad$ sediment grain size fractions $(<0.063 \mathrm{~mm} ;>0.063<0.5 \mathrm{~mm} ;>0.5<2 \mathrm{~mm} ;>2 \mathrm{~mm})(\mathrm{E}) ;$ and stable carbon isotopes signatures of soil organic matter $\left(\delta^{13} \mathrm{C} ; \%\right.$ o $)(\mathrm{F})$ in tidal marsh soils under different geomorphic settings (fluvial, intermediate and marine) in temperate Western Australia. Results of PERMANOVA pairwise tests to assess differences are denoted: different letters $(\mathrm{A}, \mathrm{B}, \mathrm{C})$ indicate significant differences $\left(P<0.01\right.$ in all cases, except for $\mathrm{C}_{\text {org }}$ stocks $\left.(P<0.05)\right)$.

$\mathrm{C}_{\text {org }}$ and $27.0 \pm 0.9 \mathrm{mg} \mathrm{C}_{\text {org }} \mathrm{cm}^{-3}$; Figure $2 \mathrm{~B}$ ). This trend was reversed for DBD in fluvial, intermediate and marine settings $\quad\left(0.87 \pm 0.03 \mathrm{~g} \mathrm{~cm}^{-3}\right.$; $0.93 \pm 0.02 \mathrm{~g} \mathrm{~cm}^{-3} ; \quad$ and $\quad 1.19 \pm 0.02 \mathrm{~g} \mathrm{~cm}^{-3}$, respectively; $P<0.01$, Figure $2 \mathrm{~A}$ ). Fluvial and intermediate tidal marsh soils contained more than twofold higher silt and clay sediment particles than marine counterparts $(49 \pm 3 \%, 47 \pm 4 \%$, and $23 \pm 4 \%$, respectively; $P<0.01$, Figure $2 \mathrm{E}$ ), while marine tidal marsh had up to 94-fold higher 
$\mathrm{CaCO}_{3}$ content $(28.3 \pm 2.9 \%)$ than fluvial $(0.3 \pm 0.2 \%)$ and intermediate $(5.1 \pm 1.6 \%)$ counterparts $(P<0.01$, Figure $2 \mathrm{D})$.

The PCA identified two principle components (PC1 and PC2) which explain $49 \%$ and $18 \%$ of the variability, respectively (Figure 3). Samples were broadly spread by geomorphic settings along PCl with marine samples clustering at positive values. Intermediate and fluvial samples tended towards more negative values on $\mathrm{PCl}$, though there was little distinction between the two. PCA scores showed that this spread of samples is related to the composition of the mineral substrate $\left(\mathrm{CaCO}_{3}\right.$ content $v s$. silt and clay content), proportion of organic matter and source of $\mathrm{C}_{\text {org }}\left(\% \mathrm{C}_{\text {org }}\right.$ vs. DBD and $\left.\delta^{13} \mathrm{C}\right)$.

Marine-situated tidal marsh had significantly depleted ${ }^{13} \mathrm{C}$ values (averaging $-22.7 \pm 0.6 \%$ ) compared to those in fluvial settings $(-24.6$ $\pm 0.2 \% ; P<0.01$; Figure $2 \mathrm{~F})$. Downcore enrichment of ${ }^{13} \mathrm{C}$ from surface $(<20 \mathrm{~cm})$ to sub-surface $(>20 \mathrm{~cm})$ soils was highest in fluvial and intermediate $\left(2.1 \%\right.$ and $1.4 \%$ increase in $\delta^{13} \mathrm{C}$ values, respectively) compared to marine tidal marshes $\left(0.6 \%\right.$ increase in $\delta^{13} \mathrm{C}$ values; Table S3). The

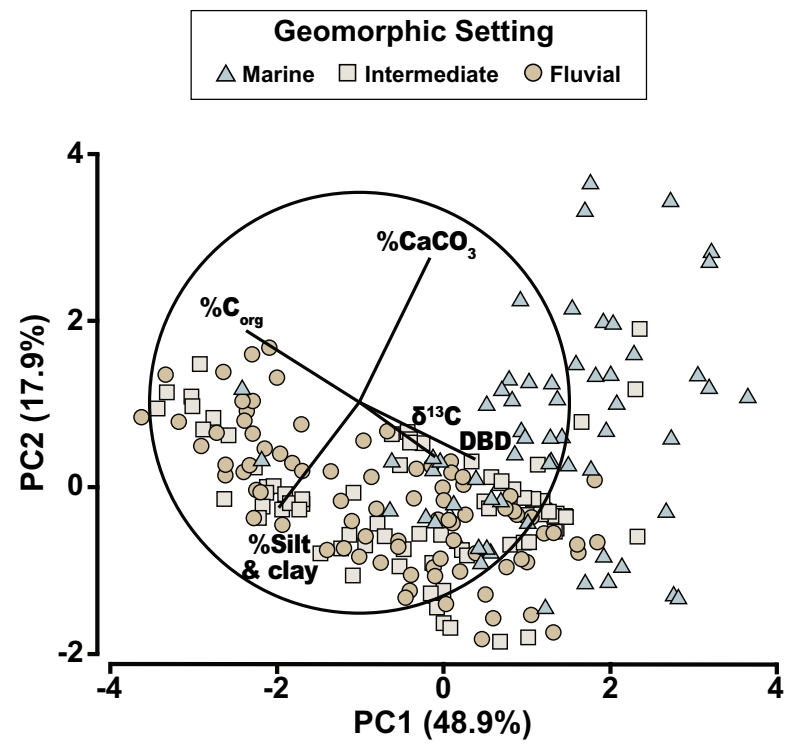

Figure 3. Principal component analysis (PCA) biplot of soil biogeochemical variables as vectors $(N=236)$ and tidal marsh sites colour coded per geomorphic setting. The soil variables included organic carbon content $\left(\% \mathrm{C}_{\mathrm{org}}\right)$, dry bulk density (DBD), calcium carbonate content $\left(\% \mathrm{CaCO}_{3}\right)$, silt and clay content ( $\%$ silt $\delta$ clay) and the $\delta^{13} \mathrm{C}$ isotopic composition $\left(\delta^{13} \mathrm{C}\right)$. Opposite vectors are negatively correlated, vectors separated by small angles are positively correlated, and perpendicular vectors are uncorrelated. Higher variability is indicated by longer length of vectors. mixing models applied indicate that source material depleted in ${ }^{13} \mathrm{C}$ was the dominant contributor of soil $\mathrm{C}_{\text {org }}$ in fluvial $(80 \%)$, intermediate $(76 \%)$ and marine $(57 \%)$ tidal marsh, except for J. kraussiidominated marine sites where source material depleted in ${ }^{13} \mathrm{C}$ explained a lesser $(46 \%)$ contribution (Figure 4).

There were no significant differences in soil $\mathrm{C}_{\text {org }}$ stocks between the two vegetation communities assessed: J. kraussii $\left(202 \pm 13 \mathrm{Mg} \mathrm{C}_{\mathrm{org}} \mathrm{ha}^{-1}\right)$ and $S$. quinqueflora (185 $\pm 13 \mathrm{Mg} \mathrm{C}_{\mathrm{org}} \mathrm{ha}^{-1} ; P>0.05$, Figure 5A). Furthermore, no significant correlations were found between soil $\mathrm{C}_{\text {org }}$ stocks and distance to open water $\left(R^{2}=0.093\right)$, estuary entrance condition $(P>0.05$; Figure $5 \mathrm{~B})$, or core location within tidal marsh habitat (water's edge, middle of tidal marsh and fringing vegetation; $P>0.05$, Figure 5C).

\section{Discussion}

The average soil $\mathrm{C}_{\text {org }}$ stocks (in 1 -m-thick deposits) of temperate WA tidal marsh (194 $\left.\pm 9 \mathrm{Mg} \mathrm{C}_{\text {org }} \mathrm{ha}^{-1}\right)$ fall above worldwide estimates $\left(162 \pm 259 \mathrm{Mg} \mathrm{C}_{\text {org }}\right.$ $\mathrm{ha}^{-1}$; Duarte and others 2013). However, the mean soil $\mathrm{C}_{\text {org }}$ stock measured in temperate WA tidal marshes is lower than in northeast Canada (357 $\pm 15 \mathrm{Mg} \mathrm{C}_{\text {org }} \mathrm{ha}^{-1}$; Chmura and others 2003), the contiguous USA (USA; $270 \pm 14 \mathrm{Mg}$ $\mathrm{C}_{\text {org }}$ ha $^{-1}$; Holmquist and others 2018) and Europe (255 $\mathrm{Mg} \mathrm{C}_{\text {org }} \mathrm{ha}^{-1}$, ranging 180-410 $\mathrm{Mg} \mathrm{C}_{\text {org }} \mathrm{ha}^{-1}$; Chmura and others 2003; Mueller and others 2019), but similar than in China (189 $\mathrm{Mg} \mathrm{C}_{\text {org }} \mathrm{ha}^{-1}$, ranging 84-1560 $\mathrm{Mg} \mathrm{C}_{\text {org }}$ ha $^{-1}$; Zheng and others 2013; Ye and others 2015; Xiao and others 2019) and higher than in the United Arab Emirates (UAE; $80 \pm 18 \mathrm{Mg} \mathrm{C}_{\text {org }}$ ha $^{-1}$; Schile and others 2017). Differences between temperate WA's tidal marsh soil $\mathrm{C}_{\text {org }}$ stocks and the global tidal marsh carbon stocks can be largely attributed to the intensity of relative sea-level rise (RSLR) during the Holocene (Rogers and others 2019). The temperate WA region experienced a mid-Holocene highstand approximately $+2 \mathrm{~m}$ above present sea levels around six thousand years ago, followed by sea levels declining linearly before returning to present levels approximately 1.5 thousand years ago (Collins and others 2006; Lewis and others 2013). The relative stability of WA's sea level likely reduced the soil $\mathrm{C}_{\text {org }}$ storage capacity in the region as it limited both vertical and lateral accommodation space, ultimately decreasing the potential for mineral and organic material accumulation and landward encroachment. Conversely, tidal marsh situated along tectonically active coastlines and/or 


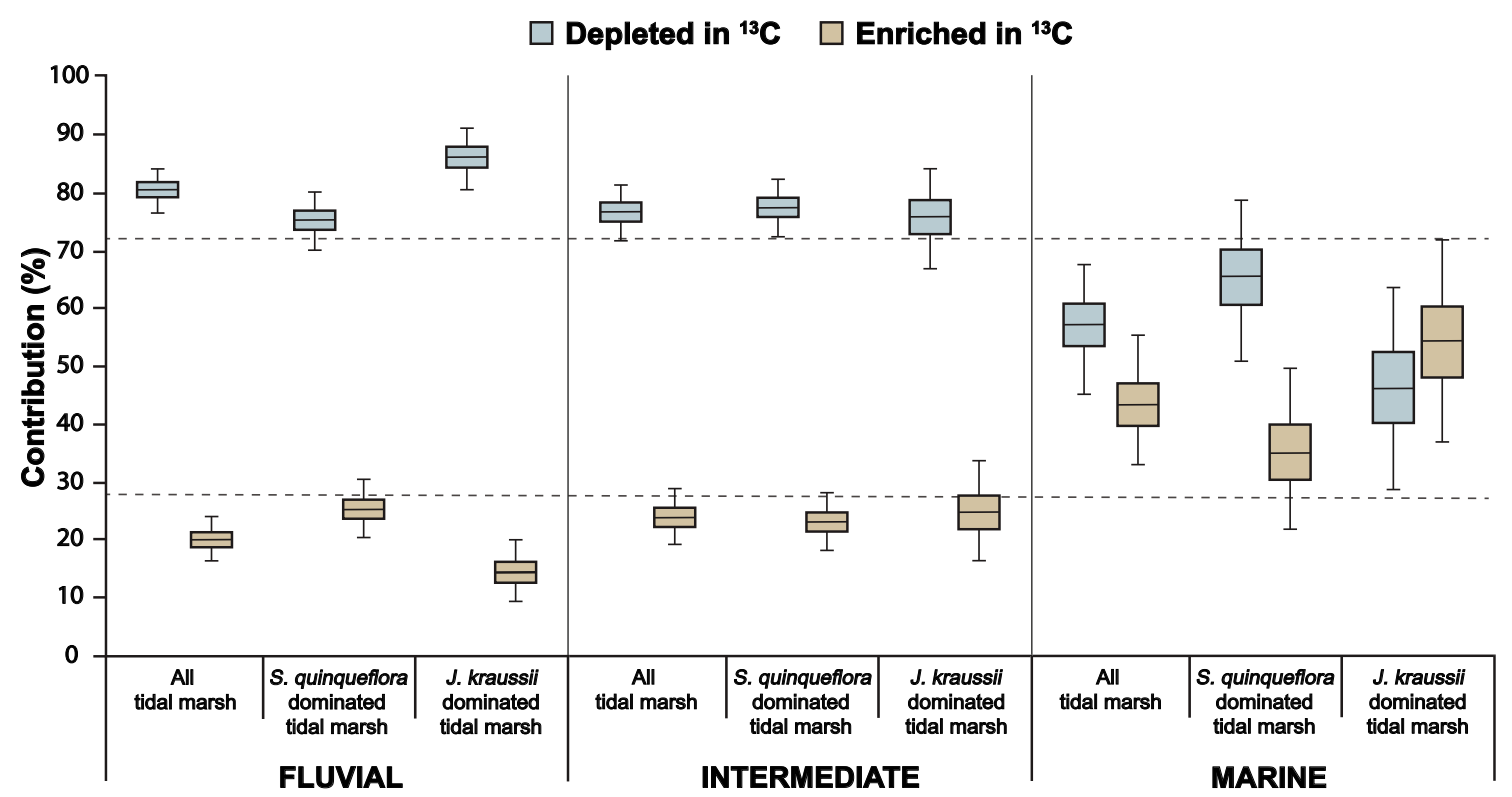

Figure 4. Isotopic mixing model results showing the proportional input ( $25 \%, 50 \%$ and $75 \%$ quantiles) of organic source materials (depleted in ${ }^{13} \mathrm{C}$ and enriched in ${ }^{13} \mathrm{C}$ ) in $1-\mathrm{m}$-thick tidal marsh soils. Three mixing models were run comprising: all sampled tidal marsh, Sarcocornia quinqueflora-dominated tidal marsh and Juncus kraussii-dominated tidal marsh under different geomorphic settings (fluvial, intermediate and marine) in temperate WA. Dotted lines represent the proportional median input of organic source material as analysed across all cores (depleted in ${ }^{13} \mathrm{C}=72.4 \%$ and enriched in $\left.{ }^{13} \mathrm{C}=27.6 \%\right)$.

closer to the maximal ice sheet extent during the last glacial period (that is, regions in Canada, the USA and Europe) were subject to higher rates of RSLR during the Holocene and, therefore, likely experienced an increase in accommodation space and subsequent soil $\mathrm{C}_{\text {org }}$ sequestration (Rogers and others 2019). The larger soil $C_{\text {org }}$ stocks in temperate WA compared to those of the UAE, which maintained a similarly stable sea level during the Holocene, likely stems from multifaceted physical (for example, topography, inundation), chemical (for example, recalcitrance of organic matter) and biological (for example, species composition, productivity) interactions (Campbell and others 2014; Almahasheer and others 2017). For example, the arid climate of the UAE offers higher mean temperatures and lower rates of precipitation than temperate WA, thereby increasing evaporation and promoting hypersaline conditions which reduce tidal marsh plant productivity and increase soil $\mathrm{C}_{\text {org }}$ decomposition (Laegdsgaard 2006; Schile and others 2017).

The range of soil $\mathrm{C}_{\text {org }}$ stocks estimated in this study (71-427 $\mathrm{Mg} \mathrm{C}_{\text {org }} \mathrm{ha}^{-1}$ ) falls within previous estimates of tidal marsh soil $\mathrm{C}_{\text {org }}$ stocks in temperate Australia (14-962 $\mathrm{Mg} \mathrm{C}_{\text {org }}$ ha $^{-1}$; Macreadie and others 2017). However, previous estimates of soil $\mathrm{C}_{\text {org }}$ stocks in WA tidal marshes $\left(91 \pm 10 \mathrm{Mg} \mathrm{C}_{\text {org }}\right.$ $\mathrm{ha}^{-1}$; Macreadie and others 2017) were more than twofold lower than the estimates in our study. This is likely a result of the previous estimates stemming from a limited data set from few locations $(N=10$ cores across two locations) which focused on four seasonally dry (dry during summer months) tidal marsh ecosystems. The seasonally dry ecology of the tidal marsh sampled by Macreadie and others (2017) would likely enhance remineralisation rates of $\mathrm{C}_{\text {org }}$ and thereby result in relatively lower soil $\mathrm{C}_{\text {org }}$ stocks compared to the microtidal tidal marshes studied here, which are typical in temperate WA. The seasonally dry nature of tidal marshes reported by Macreadie and others (2017) is linked to floodgate tidal restrictions at the Vasse Wonnerup wetlands (DoW 2010) and the limited water inflow from subterranean oceanic vents and seasonal flooding of the semi-arid Lake MacLeod system located about $20 \mathrm{~km}$ inland (DEC 2009). Conversely, the revised assessment of WA temperate tidal marsh soil $\mathrm{C}_{\text {org }}$ stocks presented here provides a representative and robust estimate of temperate WA, which can be used to further develop blue carbon climate mitigation strategies globally and within Australia under the Emission Reduction Fund (ERF; Kelleway and others 2017a).

Temperate WA tidal marshes situated in fluvial and intermediate settings hold on average 1.3- 


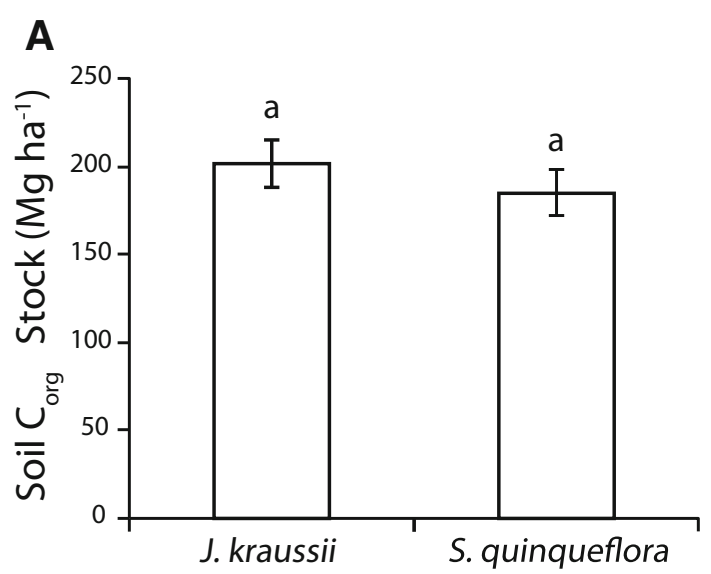

B
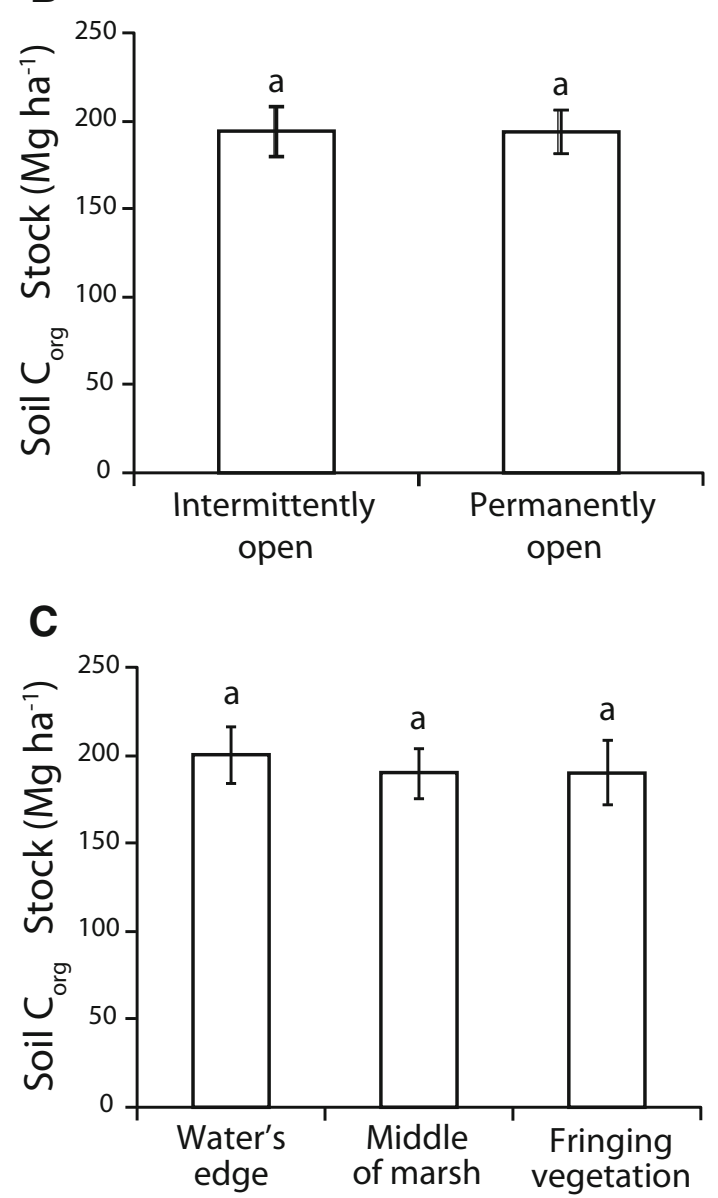

Figure 5. Mean $( \pm \mathrm{SE})$ soil organic carbon stocks ( $\mathrm{Mg} \mathrm{ha}^{-1}$ in 1-m-thick soils) in Juncus kraussii- and Sarcocornia quinqueflora-dominated tidal marsh (A); estuary entrance condition (intermittently and permanently open) (B); and core transect position (water's edge, middle of tidal marsh and fringing vegetation) (C) in temperate Western Australia. Results of PERMANOVA pairwise tests to assess differences are denoted: different letters $(\mathrm{A}, \mathrm{B}, \mathrm{C})$ indicate significant differences $(P<0.01)$. times greater soil $\mathrm{C}_{\text {org }}$ stocks than their marine counterparts, in agreement with previous trends described for other Australian and western European tidal marshes (Kelleway and others, 2016; Macreadie and others 2017; Van De Broek and others 2016). The differences in soil $\mathrm{C}_{\text {org }}$ storage at the within-estuary spatial scale are likely explained by the twofold higher silt and clay contents observed in fluvial and intermediate settings compared to those in marine settings. Fine-grained sediments decrease drainage rates and oxygen exposure time in soils, thereby lowering the redox potential and allowing for higher retention and preservation of $\mathrm{C}_{\text {org }}$ (Hedges and Keil 1995; Kelleway and others 2016). The two exceptions to this trend were found at Culham Inlet and Hardy Inlet, with relatively higher soil $\mathrm{C}_{\text {org }}$ stocks in marine and intermediate tidal marsh, respectively, compared to fluvial counterparts. This may be explained by the higher silt and clay contents identified in the marine tidal marsh of Culham Inlet $30 \%$ higher than fluvial) and the intermediate tidal marsh of Hardy inlet (15\% higher than fluvial), reflecting higher rates of deposition within these settings. For instance, the Culham Inlet is rarely open to the ocean (once every few decades; Brearley 2006), which could result in the accumulation of terrestrial fine sediments within the lower reaches around our marine sampling site, while potential differences in habitat elevation may influence the depositional characteristics of tidal marsh in the Hardy Inlet. However, further studies (for example, hydrodynamic model, elevation tables) are required to decipher potential causes.

The differences observed in soil $\mathrm{C}_{\text {org }}$ stocks between fluvial and marine settings in temperate WA are narrower than those identified in estuaries along the temperate east coast of Australia ( $>$ twofold differences; Kelleway and others 2016) or in the European Scheldt River ( $>$ threefold differences; Van De Broek and others 2016). Sediment deposition on tidal marsh surfaces is reliant on the availability of suspended sediments in the water column and is principally driven by flooding events, including water elevations which barely overflow the shore bank to high spring tide events (Christiansen and others 2000). Owing to the microtidal nature of temperate WA's coastline, which differs from the flooding- and tidal-driven dynamics in estuaries along the east coast of Australia, sediment deposition in upstream marshes may be driven by rainfall events and river inflow. Temperate WA has about 30\% lower mean annual precipitation rates compared to those of temperate eastern Australia (824 and 1129 mm, respectively; 
Department of the Environment 2015; Bureau of Meteorology 2020), which results in lower river inflow and may explain the lower soil $\mathrm{C}_{\text {org }}$ stocks in the former. Low levels of precipitation would subsequently reduce the availability of suspended finegrained mineral and organic materials from upstream sources, as well as decrease the frequency and intensity of inundation events, thereby lowering opportunity for sediment deposition. However, it is important to note that the precipitation gradient along temperate WA's coastline is high (range of 450-1400 mm; Hodgkin and Hesp (1998)) and catchment size varies among estuaries. As such, further research is needed to explore the potential relationship of precipitation rates and the $\mathrm{C}_{\text {org }}$ storage potential of upstream tidal marsh habitats.

Stable isotope analysis offered insight into the source organic material preserved in tidal marsh soils, as well as the stability of soil $\mathrm{C}_{\text {org }}$ in temperate WA's tidal marshes. The naturally depleted $\delta^{13} \mathrm{C}$ values of surface $(<20 \mathrm{~cm})$ and sub-surface $(>20 \mathrm{~cm})$ soils in fluvial and intermediate tidal marshes are indicative of higher inputs from C3 vascular plants (that is, intertidal halophytes and terrestrial plant litter) compared to marine counterparts. However, as J. kraussii, S. quinqueflora and the surrounding supratidal vegetation have similarly depleted $\delta^{13} \mathrm{C}$ signatures, it is not clear which proportion of these originate from autochthonous (produced within the tidal marsh) or allochthonous $\mathrm{C}_{\text {org }}$ inputs (imported from adjacent terrestrial ecosystems). Further studies would be required to clarify this question in WA temperate tidal marshes and elsewhere, such as the use of eDNA and molecular techniques (Geraldi and others 2019). The $1-3 \%$ increase in $\delta^{13} \mathrm{C}$ values together with a decrease in $\% \mathrm{C}_{\text {org }}$ with depth in fluvial and intermediate tidal marshes suggests isotopic fractionation during $\mathrm{C}_{\text {org }}$ decomposition due to selective preservation of organic compounds depleted in ${ }^{13} \mathrm{C}$ (Adame and Fry 2016).

The higher soil $\mathrm{C}_{\text {org }}$ stocks in fluvial and intermediate compared to marine settings could be partially explained by the higher inputs of tidal marsh and supratidal vegetation in the soil $\mathrm{C}_{\text {org }}$ pool, which have lower decay rates than those of macroalgae and seagrass (Enríquez and others 1993). Furthermore, the relatively higher inputs of oceanic nutrients expected in marine-situated tidal marsh may reduce root production, thereby lowering soil $\mathrm{C}_{\text {org }}$ stocks in these settings (Darby and Turner 2008). This is supported by marine-located tidal marsh having accumulated approximately $25 \%$ more $\mathrm{C}_{\text {org }}$ enriched in ${ }^{13} \mathrm{C}$ than their fluvial counterparts, which likely reflects a proportional increase in the deposition of allochthonous plants with less negative $\delta^{13} \mathrm{C}$ values, reflective of the different photosynthetic pathways (that is, seagrasses, many species of macroalgae and marine seston) in marine-situated marshes. Surprisingly, tidal marsh soils dominated by J. kraussii had approximately $30 \%$ more contribution of $\mathrm{C}_{\text {org }}$ derived from sources naturally enriched in ${ }^{13} \mathrm{C}$ compared to those dominated by $S$. quinqueflora. This finding contrasts Kelleway and others (2016) who identified higher proportions of allochthonous $\mathrm{C}_{\text {org }}$ deposits in succulent and grass-dominated marshes as opposed to rush-dominated tidal marsh. This difference can likely be attributed to the microtidal nature of temperate WA's coastline allowing for persistent low-lying tidal marsh habitats which are typically dominated, from shoreline to supratidal vegetation, by a singular plant community. This relative uniformity within sites may also explain the lack of significant difference between soil $\mathrm{C}_{\text {org }}$ stocks measured along the sampling transect within tidal marsh ecosystems (that is, water's edge, middle of tidal marsh and fringing vegetation) in temperate WA. In contrast, the flooding- and tidaldriven dynamics observed on the east coast of Australia results in increased elevational gradients and heightened habitat zonation, ultimately influencing species assemblages between low and high marshland (Kelleway and others 2017a).

The large increase in $\delta^{13} \mathrm{C}$ values with depth $(>3 \%$ ) in marine-situated tidal marsh dominated by $J$. kraussii may reflect a change in source material to the modern C3 intertidal halophytes from plant communities such as seagrass and macroalgae (Adame and Fry 2016). Alternatively, this shift may reflect relative contributions from different source material changing systematically with time in response to the balance between available accommodation space and vertical accretion. However, as this downcore enrichment of $\delta^{13} \mathrm{C}$ reflects soil profiles of oxic terrestrial sediments (Natelhoffer and Fry 1988), it may be that this enrichment reflects the loss or degradation of proteins and the selective preservation of lignin over time due to pore water exchange and decomposition, thereby resulting in soil organic matter enriched in ${ }^{13} \mathrm{C}$ with depth (Maher and others 2017; Adame and others 2019). Indeed, declining sea levels from 6 to 1.5 thousand years ago (Collins and others 2006; Lewis and others 2013) could explain the increase in marine organic matter sources to soil $\mathrm{C}_{\text {org }}$ stocks with depth. Further studies are required to determine the age of the sedimentary deposits under- 
neath WA' tidal marshes and to estimate $\mathrm{C}_{\text {org }}$ burial rates.

This data set represents the most extensive estimates of tidal marsh soil $\mathrm{C}_{\text {org }}$ stocks throughout the western third of Australia. Following this research, the soil $\mathrm{C}_{\text {org }}$ stocks within the approximately $3000 \mathrm{~km}^{2}$ of tidal marsh ecosystems in WA (Bucher and Saenger 1991) were estimated at $57 \mathrm{Tg} \mathrm{C} \mathrm{C}_{\text {org }}$ and correspond to about $2 \%$ of worldwide tidal marsh soil $\mathrm{C}_{\text {org }}$ stocks. The inclusion of temperate WA in the national/continental estimate has increased Australia's mean tidal marsh soil $\mathrm{C}_{\text {org }}$ stocks by $6 \%$, from 165 to $176 \mathrm{Mg} \mathrm{C}_{\text {org }} \mathrm{ha}^{-1}$, and increased the total Australian blue carbon stock by $2 \%$, that is $30 \mathrm{Tg} \mathrm{C}_{\text {org }} \mathrm{ha}^{-1}$ (million tonnes; following the spatially unweighted approach of Macreadie and others (2017)). The total $\mathrm{C}_{\text {org }}$ stored in temperate WA's tidal marshes (in l-m-thick soils) is roughly equivalent to 5.5 years of total $\mathrm{CO}_{2}$ emissions by WA from all fossil fuel burning, gas flaring and cement production (WA's emissions estimated at $10.8 \mathrm{Tg}$ C at 2014 rates; CDIAC 2019). However, it is important to note that these estimates stem from a spatially limited and outdated tidal marsh areal data set which does not consider habitat loss or reclamation subsequent to 1989 (Bucher and Saenger 1991). Although this research provides a comprehensive examination of WA's temperate tidal marsh soil $\mathrm{C}_{\text {org }}$ stocks, it is possible the $\mathrm{C}_{\text {org }}$ stocks in the arid northwest of Australia reflect the relatively low $\mathrm{C}_{\text {org }}$ stocks of arid tidal marsh habitats elsewhere (Schile and others 2017). As such, future regional or continental estimates of blue carbon stocks and accumulation rates should focus on including samples from the arid northwest of WA to assess the capacity of Australia's arid tidal marshes to act as viable blue carbon reservoirs. Furthermore, there is a fundamental need to identify and quantify the distribution and coverage of Australia's tidal marshes, particularly within the tidal flats in tropical regions, in order to improve current estimates and facilitate their incorporation into national and international carbon accounting schemes.

\section{ACKNOWLEDGEMENTS}

This project was supported by Edith Cowan University and the Centre for Marine Ecosystems Research (CMER). The authors are grateful to C. Campbell, S. McNamara and F. Ran-Gelico for their help in field and/or laboratory tasks. O.S. was supported by an ARC DECRA DE170101524. C.S. was funded by ECU Higher Degree by Research Scholarship.

\section{Compliance with Ethical Standards}

Conflict of Interest The authors declare that they have no conflict of interest.

\section{OPEN ACCESS}

This article is licensed under a Creative Commons Attribution 4.0 International License, which permits use, sharing, adaptation, distribution and reproduction in any medium or format, as long as you give appropriate credit to the original author(s) and the source, provide a link to the Creative Commons licence, and indicate if changes were made. The images or other third party material in this article are included in the article's Creative Commons licence, unless indicated otherwise in a credit line to the material. If material is not included in the article's Creative Commons licence and your intended use is not permitted by statutory regulation or exceeds the permitted use, you will need to obtain permission directly from the copyright holder. To view a copy of this licence, visit http://creativecommons.org/licenses/by/4.0/.

\section{REFERENCES}

Adam P. 1990. Saltmarsh Ecology. Cambridge University Press h ttps://books.google.com.au/books?hl=enslr=\&id=BokNrZxql $\mathrm{r} 4 \mathrm{C} \delta \mathrm{oi}=$ fnd $\mathrm{fpg}=\mathrm{PR} 7 \delta \mathrm{dq}=$ saltmarsh + adamsots $=\mathrm{q} 9 \mathrm{CiNgJFF}$ B\&sig=wXGUp7yCrUepeICO7PO4Syt5 GqA\#v=onepagef $\mathrm{q}=\mathrm{la}$ titudeff=false. Last accessed 09/08/2019.

Adame MF, Fry B. 2016. Source and stability of soil carbon in mangrove and freshwater wetlands of the Mexican Pacific coast. Wetl Ecol Manag 24:129-37.

Adame MF, Reef R, Wong VN, Balcombe SR, Turschwell MP, Kavehei E, Rodríguez DC, Kelleway JJ, Masque P, Ronan M. 2019. Carbon and nitrogen sequestration of melaleuca floodplain wetlands in tropical Australia. Ecosystems. https://doi. org/10.1007/s10021-019-00414-5.

Almahasheer H, Serrano O, Duarte CM, Arias-Ortiz A, Masque P, Irigoien X. 2017. Low Carbon sink capacity of Red Sea mangroves. Sci Rep 7:1-10.

Alongi DM. 2018. Salt Marshes. In: Blue Carbon: Coastal Sequestration for Climate Change Mitigation. Annandale, QLD: Springer International Publishing. pp 9-22. http://link. springer.com/10.1007/978-3-319-91698-9_2. Last accessed 08/10/2019.

Alongi DM, Murdiyarso D, Fourqurean JW, Kauffman JB, Hutahaean A, Crooks S, Lovelock CE, Howard J, Herr D, Fortes M, Pidgeon E, Wagey T. 2016. Indonesia's blue carbon: a globally significant and vulnerable sink for seagrass and mangrove carbon. Wetl Ecol Manag 24:3-13. http://link.spri nger.com/10.1007/s11273-015-9446-y. Last accessed 09/08/ 2019.

Arias-Ortiz A, Serrano O, Masqué P, Lavery PS, Mueller U, Kendrick GA, Rozaimi M, Esteban A, Fourqurean JW, Marbà N, Mateo MA, Murray K, Rule MJ, Duarte CM. 2018. A marine heatwave drives massive losses from the world's largest seagrass carbon stocks. Nat Clim Chang 8:338-344. http:// 
www.nature.com/articles/s41558-018-0096-y. Last accessed 27/08/2019.

Baustian MM, Stagg CL, Perry CL, Moss LC, Carruthers TJB, Allison M. 2017. Relationships Between Salinity and ShortTerm Soil Carbon Accumulation Rates from Marsh Types Across a Landscape in the Mississippi River Delta. Wetlands: 112. http://link.springer.com/10.1007/s13157-016-0871-3. Last accessed 15/03/2017.

Brearley A. 2006. Ernest Hodgkin's swanland: Estuaries and coastal lagoons of South-Western Australia. UWA Publishing.

Brodie CR, Leng MJ, Casford JSL, Kendrick CP, Lloyd JM, Yongqiang Z, Bird MI. 2011. Evidence for bias in C and N concentrations and $\delta 13 \mathrm{C}$ composition of terrestrial and aquatic organic materials due to pre-analysis acid preparation methods. Chem Geol 282:67-83.

Bucher D, Saenger P. 1991. An Inventory of Australian Estuaries and Enclosed Marine Waters: An Overview of Results. Aust Geogr Stud 29:370-381. http://doi.wiley.com/10.1111/j.1467 -8470.1991.tb00726.x. Last accessed 21/08/2019.

Bureau of Meteorology. 2020. Climate Data Online. http://ww w.bom.gov.au/climate/data/index.shtml. Last accessed 27/01/ 2020.

Butzeck C, Eschenbach A, Gröngröft A, Hansen K, Nolte S, Jensen K. 2014. Sediment Deposition and Accretion Rates in Tidal Marshes Are Highly Variable Along Estuarine Salinity and Flooding Gradients. Estuaries and Coasts 38:434-50.

Campbell JE, Lacey EA, Decker RA, Crooks S, Fourqurean JW. 2014. Carbon Storage in Seagrass Beds of Abu Dhabi, United Arab Emirates. Estuaries and Coasts 38:242-51.

CDIAC. 2019. Carbon Dioxide Information Analysis Center. https://cdiac.ess-dive.lbl.gov/. Last accessed 14/12/2019.

Chmura GL, Anisfeld SC, Cahoon DR, Lynch JC. 2003. Global carbon sequestration in tidal, saline wetland soils. Global Biogeochem Cycles 17:n/a-n/a. http://doi.wiley.com/10.102 9/2002GB001917. Last accessed 28/05/2017.

Christiansen T, Wiberg PL, Milligan TG. 2000. Flow and sediment transport on a tidal salt marsh surface. Estuar Coast Shelf Sci 50:315-31.

Collins LB, Zhao JX, Freeman H. 2006. A high-precision record of mid-late Holocene sea-level events from emergent coral pavements in the Houtman Abrolhos Islands, southwest Australia. Quat Int 145-146:78-85.

Darby F, Turner R. 2008. Effects of eutrophication on salt marsh root and rhizome biomass accumulation. Mar Ecol Prog Ser 363:63-70. http://www.int-res.com/abstracts/meps/v363/p63 -70/. Last accessed 07/04/2020.

Department of the Environment. 2015. Conservation Management Zones of Australia-South Western Australia Temperate Forests. http://www.environment.gov.au/system/files/resour ces/91 db6d64-a320-46b2-8328-8920bflbe6e8/files/cmz-sout h-western-australia-temperate-forests.pdf. Last accessed 01/ $02 / 2019$.

Department of Environment and Conservation (DEC). 2009. Resource Condition Report for a Significant Western Australian Wetland: Lake MacLeod System. Perth, Western Australia https://www.dpaw.wa.gov.au/images/documents/conse rvation-management/wetlands/rcm029_lake_macleod_condit ion_report.pdf. Last accessed 27/03/2020.

Department of Water (DoW). 2010. Vasse Wonnerup Wetlands and Geographe Bay water quality improvement plan. Perth, Western Australia https://www.water.wa.gov.au/_data/asse ts/pdf_file/0017/3329/92284.pdf. Last accessed 27/03/2020.
Donato DC, Kauffman JB, Murdiyarso D, Kurnianto S, Stidham M, Kanninen M. 2011. Mangroves among the most carbonrich forests in the tropics. Nat Geosci 4:293-297. http://www. nature.com/articles/ngeol 123. Last accessed 09/08/2019.

Duarte CM, Losada IJ, Hendriks IE, Mazarrasa I, Marbà N. 2013. The role of coastal plant communities for climate change mitigation and adaptation. Nat Clim Chang 3:961-968. http:// www.nature.com/articles/nclimate1970. Last accessed 27/06/ 2019.

Enríquez S, Duarte CM, Sand-Jensen K. 1993. Patterns in decomposition rates among photosynthetic organisms: the importance of detritus C:N: P content. Oecologia 94:457-71.

Fourqurean JW, Duarte CM, Kennedy H, Marbà N, Holmer M, Mateo MA, Apostolaki ET, Kendrick GA, Krause-Jensen D, McGlathery KJ, Serrano O. 2012a. Seagrass ecosystems as a globally significant carbon stock. Nat Geosci 5:505-509. htt p://www.nature.com/doifinder/10.1038/ngeol477. Last accessed 30/03/2017.

Fourqurean JW, Kendrick GA, Collins LS, Chambers RM, Vanderklift MA. 2012b. Carbon, nitrogen and phosphorus storage in subtropical seagrass meadows: examples from Florida Bay and Shark Bay. Mar Freshw Res 63:967. http://www.publish.c siro.au/?paper=MF12101. Last accessed 20/11/2019.

Geoscience Australia. 2004. Border Lengths-States and Territories. http://www.ga.gov.au/scientific-topics/national-locatio n-information/dimensions/border-lengths. Last accessed 24/ $11 / 2019$.

Geraldi NR, Ortega A, Serrano O, Macreadie PI, Lovelock CE, Krause-Jensen D, Kennedy H, Lavery PS, Pace ML, Kaal J, Duarte CM. 2019. Fingerprinting Blue Carbon: Rationale and Tools to Determine the Source of Organic Carbon in Marine Depositional Environments. Front Mar Sci 6:263.

Glew JR, Smol JP, Last WM. 2005. Sediment Core Collection and Extrusion. In: Tracking Environmental Change Using Lake Sediments. Kluwer Academic Publishers. pp 73-105.

Hedges JI, Keil RG. 1995. Sedimentary organic matter preservation: an assessment and speculative synthesis. Mar Chem 49:81-115. https://linkinghub.elsevier.com/retrieve/pii/0304 42039500008F. Last accessed 09/08/2019.

Hodgkin E, Hesp P. 1998. Estuaries to salt lakes: Holocene transformation of the estuarine ecosystems of south-western Australia. Mar Freshw Res 49:183-201.

Holmquist JR, Windham-Myers L, Bliss N, Crooks S, Morris JT, Megonigal JP, Troxler T, Weller D, Callaway J, Drexler J, Ferner MC, Gonneea ME, Kroeger KD, Schile-Beers L, Woo I, Buffington K, Breithaupt J, Boyd BM, Brown LN, Dix N, Hice L, Horton BP, MacDonald GM, Moyer RP, Reay W, Shaw T, Smith E, Smoak JM, Sommerfield C, Thorne K, Velinsky D, Watson E, Grimes KW, Woodrey M. 2018. Accuracy and Precision of Tidal Wetland Soil Carbon Mapping in the Conterminous United States. Sci Rep 8:9478. http://www.nature.c om/articles/s41598-018-26948-7. Last accessed 24/06/2019.

Horváth B, Opara-Nadi O, Beese F. 2005. A simple method for measuring the carbonate content of soils. Soil Sci Soc Am J 69:1066-8.

Kelleway JJ, Saintilan N, Macreadie PI, Ralph PJ. 2016. Sedimentary Factors are Key Predictors of Carbon Storage in SE Australian Saltmarshes. Ecosystems 19:865-880. http://link. springer.com/10.1007/s10021-016-9972-3. Last accessed 31/ 05/2017.

Kelleway JJ, Macreadie P, Baldock J, Ralph P. 2017a. Sediment and carbon accumulation vary among vegetation assemblages 
in a coastal saltmarsh. Biogeosciences. https://www.research gate.net/publication/313317176. Last accessed 23/07/2019.

Kelleway JJ, Saintilan N, Macreadie PI, Baldock JA, Heijnis H, Zawadzki A, Gadd P, Jacobsen G, Ralph PJ. 2017b. Geochemical analyses reveal the importance of environmental history for blue carbon sequestration. J Geophys Res Biogeosciences 122:1789-1805. http://doi.wiley.com/10.1002/2 017JG003775. Last accessed 18/09/2019.

Komada T, Anderson MR, Dorfmeier CL. 2008. Carbonate removal from coastal sediments for the determination of organic carbon and its isotopic signatures, $\delta^{13} \mathrm{C}$ and $\Delta^{14} \mathrm{C}$ : comparison of fumigation and direct acidification by hydrochloric acid. Limnol Oceanogr Methods 6:254-262. http://doi.wiley.com/ 10.4319/lom.2008.6.254. Last accessed 28/05/2020.

Laegdsgaard P. 2006. Ecology, disturbance and restoration of coastal saltmarsh in Australia: a review. Wetl Ecol Manag 14:379-399. http://link.springer.com/10.1007/s1 1273-005-8 827-z. Last accessed 28/05/2017.

Lewis SE, Sloss CR, Murray-Wallace CV, Woodroffe CD, Smithers SG. 2013. Post-glacial sea-level changes around the Australian margin: A review. Quat Sci Rev 74:115-38.

Macreadie P, Ollivier Q, Kelleway J, Serrano O, Carnell P, Ewers C, Atwood T, Sanderman J, Baldock J, Connolly R, Duarte C, Lavery P, Steven A, Lovelock C. 2017. Carbon sequestration by Australian tidal marshes. Sci Rep 7:44071. http://www.na ture.com/articles/srep44071. Last accessed 17/03/2017.

Maher DT, Santos IR, Schulz KG, Call M, Jacobsen GE, Sanders CJ. 2017. Blue carbon oxidation revealed by radiogenic and stable isotopes in a mangrove system. Geophys Res Lett 44:4889-96.

Mazarrasa I, Samper-Villarreal J, Serrano O, Lavery PS, Lovelock CE, Marbà N, Duarte CM, Cortés J. 2018. Habitat characteristics provide insights of carbon storage in seagrass meadows. Mar Pollut Bull 134:106-117. https://www.sciencedirect.com/ science/article/pii/S0025326X18300705. Last accessed 09/08/ 2019.

McLeod E, Chmura GL, Bouillon S, Salm R, Björk M, Duarte CM, Lovelock CE, Schlesinger WH, Silliman BR. 2011. A blueprint for blue carbon: Toward an improved understanding of the role of vegetated coastal habitats in sequestering $\mathrm{CO}_{2}$. Front Ecol Environ 9:552-560. http://doi.wiley.com/10.1890/ 110004. Last accessed 15/03/2017.

Mcowen C, Weatherdon L, Bochove J-W, Sullivan E, Blyth S, Zockler C, Stanwell-Smith D, Kingston N, Martin C, Spalding M, Fletcher S. 2017. A global map of saltmarshes. Biodivers Data J 5:el1764. http://bdj.pensoft.net/articles.php?id=1176 4. Last accessed 28/05/2017.

Mueller P, Ladiges N, Jack A, Schmiedl G, Kutzbach L, Jensen K, Nolte S. 2019. Assessing the long-term carbon-sequestration potential of the semi-natural salt marshes in the European Wadden Sea. Www.esajournals.org. Last accessed 26/08/2019.

Natelhoffer KJ, Fry B. 1988. Controls on natural nitrogen-15 and carbon-13 abundances in forest soil organic matter. Soil Sci Am J 52:1633-40.

Nellemann C, Corcoran E, Duarte CM, Valdés L, DeYoung C, Fonseca L, Grimsditch G. 2009. Blue Carbon: The role of healthy oceans in binding carbon. Norway: GRID-Arendal h ttps://books.google.com.au/books?hl=enslr=Sid=onCVCHQ 14RoC\&oi=fnd $\delta$ pg $=$ PAl $7 \& \mathrm{dq}=$ blue + carbon + defined $\delta$ ots $=$ ZRX a8TG6r-\&sig=V-ClfjX10T4cs7Mq-Od6-EwcclQ\#v=onepage\& $\mathrm{q}=$ bluecarbondefined\&f=false. Last accessed 21/03/2017.
Parnell AC. 2019. Package 'simmr': A Stable Isotope Mixing Model. https://cran.r-project.org/web/packages/simmr/simm r.pdf. Last accessed 27/08/2019.

Parnell AC, Phillips DL, Bearhop S, Semmens BX, Ward EJ, Moore JW, Jackson AL, Grey J, Kelly DJ, Inger R. 2013. Bayesian stable isotope mixing models. Environmetrics 24:n/ a-n/a. http://doi.wiley.com/10.1002/env.2221. Last accessed 27/08/2019.

Peterson BJ. 1999. Stable isotopes as tracers of organic matter input and transfer in benthic food webs: A review. Acta Oecologica 20:479-87.

Rogers K, Kelleway JJ, Saintilan N, Megonigal JP, Adams JB, Holmquist JR, Lu M, Schile-Beers L, Zawadzki A, Mazumder D, Woodroffe CD. 2019. Wetland carbon storage controlled by millennial-scale variation in relative sea-level rise. Nature 567:91-95. http://www.nature.com/articles/s41586-019-095 1-7. Last accessed 18/09/2019.

Rovai AS, Twilley RR, Castañeda-Moya E, Riul P, Cifuentes-Jara M, Manrow-Villalobos M, Horta PA, Simonassi JC, Fonseca AL, Pagliosa PR. 2018. Global controls on carbon storage in mangrove soils. Nat Clim Chang 8:534-538. http://www.na ture.com/articles/s41558-018-0162-5. Last accessed 09/08/ 2019.

Roy PS, Williams RJ, Jones AR, Yassini I, Gibbs PJ, Coates B, West RJ, Scanes PR, Hudson JP, Nichol S. 2001. Structure and Function of South-east Australian Estuaries. Estuar Coast Shelf Sci 53:351-384. https://www.sciencedirect.com/scienc e/article/pii/S0272771401907966. Last accessed 09/08/2019.

Ryan DA, Heap AD, Radke L, Heggie D. T. 2003. Conceptual models of Australia's estuaries and coastal waterways: applications for coastal resource management. Canberra, ACT h ttp://www.ga.gov.au/webtemp/image_cache/GAl3418.pdf.

Last accessed 18/09/2019.

Saintilan N. 2009. Distribution of Australian saltmarsh plants. In: Australian saltmarsh ecology. CSIRO Pub. pp 23-36. https://b ooks.google.com.au/books?hl=enflr=\&id=Kpi9TjDQO8QCEoi=f nd\&pg=PA23\&dq=saenger $+1977+$ salt + marsh\&ots $=$ ijNVYkUeFc

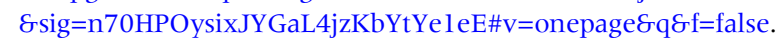
Last accessed 09/08/2019.

Saintilan N, Rogers K, Howe A. 2009. Geomorphology and habitat dynamics. In: Australian saltmarsh ecology. CSIRO Pub. pp 53-74. https://books.google.com.au/books?hl=en\&lr= \&id=Kpi9TjDQO8QC\&oi=fnd $\delta$ pg $=$ PA23 $\delta$ dq=saenger $+1977+$ s alt + marsh\&ots=ijNVYkUeFcEsig=n70HPOysixJYGaL4jzKbYtY eleE\#v=onepagefq\&f=false. Last accessed 09/08/2019.

Saintilan N, Rogers K, Mazumder D, Woodroffe C. 2013. Allochthonous and autochthonous contributions to carbon accumulation and carbon store in southeastern Australian coastal wetlands. Estuar Coast Shelf Sci 128:84-92. http://lin kinghub.elsevier.com/retrieve/pii/S0272771413002333. Last accessed 31/05/2017.

Schile LM, Kauffman JB, Crooks S, Fourqurean JW, Glavan J, Megonigal JP. 2017. Limits on carbon sequestration in arid blue carbon ecosystems. Ecol Appl 27:859-874. http://doi.wile y.com/10.1002/eap.1489. Last accessed 27/06/2019.

Schlacher TA, Connolly RM. 2014. Effects of acid treatment on carbon and nitrogen stable isotope ratios in ecological samples: a review and synthesis. Kurle C, editor. Methods Ecol Evol 5:541-550. http://doi.wiley.com/10.1111/2041-210X.12183. Last accessed 18/11/2019.

Semeniuk V. 2000. Sedimentology and Holocene stratigraphy of Leschenault Inlet. J R Soc West Aust 83:255-73. 
Serrano O, Ricart AM, Lavery PS, Mateo MA, Arias-Ortiz A, Masque P, Rozaimi M, Steven A, Duarte CM. 2016. Key biogeochemical factors affecting soil carbon storage in Posidonia meadows. Biogeosciences 13:4581-4594. http://www.b iogeosciences.net/13/4581/2016/. Last accessed 12/04/2017.

Serrano O, Lovelock CE, Atwood TB, Macreadie PI, Canto R, Phinn S, Arias-Ortiz A, Bai L, Baldock J, Bedulli C, Carnell P, Connolly RM, Donaldson P, Esteban A, Ewers Lewis CJ, Eyre BD, Hayes MA, Horwitz P, Hutley LB, Kavazos CRJ, Kelleway JJ, Kendrick GA, Kilminster K, Lafratta A, Lee S, Lavery PS, Maher DT, Marbà N, Masque P, Mateo MA, Mount R, Ralph PJ, Roelfsema C, Rozaimi M, Ruhon R, Salinas C, SamperVillarreal J, Sanderman J, Sanders CJ, Santos I, Sharples C, Steven ADL, Cannard T, Trevathan-Tackett SM, Duarte CM. 2019. Australian vegetated coastal ecosystems as global hotspots for climate change mitigation. Nat Commun. https://doi. org/10.1038/s41467-019-12176-8.

Smit AJ, Brearley A, Hyndes GA, Lavery PS, Walker DI. 2005. Carbon and nitrogen stable isotope analysis of an Amphibolis griffithii seagrass bed. Estuar Coast Shelf Sci 65:545-556. https://www.sciencedirect.com/science/article/pii/S02727714 05002386. Last accessed 09/09/2019.

Svensson CJ, Hyndes GA, Lavery PS. 2007. Food web analysis in two permanently open temperate estuaries: Consequences of saltmarsh loss? Mar Environ Res 64:286-304. https://linkingh ub.elsevier.com/retrieve/pii/S0141113607000293. Last accessed 06/09/2019.

Ullman R, Bilbao-Bastida V, Grimsditch G. 2013. Including Blue Carbon in climate market mechanisms. Ocean Coast Manag 83:15-18. http://linkinghub.elsevier.com/retrieve/pii/S09645 69112000440. Last accessed 29/03/2017. van Ardenne LB, Jolicouer S, Bérubé D, Burdick D, Chmura GL. 2018. The importance of geomorphic context for estimating the carbon stock of salt marshes. Geoderma 330:264-275. https://linkinghub.elsevier.com/retrieve/pii/S0016706117317 172. Last accessed 09/08/2019.

Van De Broek M, Temmerman S, Merckx R, Govers G. 2016. Controls on soil organic carbon stocks in tidal marshes along an estuarine salinity gradient. Biogeosciences 13:6611-6624. www.biogeosciences.net/13/6611/2016/. Last accessed 09/08/ 2019.

Xiao D, Deng L, Kim D, Huang C, Tian K. 2019. Carbon budgets of wetland ecosystems in China. Glob Chang Biol 25:20612076. https://onlinelibrary.wiley.com/doi/abs/10.1111/gcb.1 4621. Last accessed 26/08/2019.

Ye S, Laws EA, Yuknis N, Ding X, Yuan H, Zhao G, Wang J, Yu X, Pei S, DeLaune RD. 2015. Carbon Sequestration and Soil Accretion in Coastal Wetland Communities of the Yellow River Delta and Liaohe Delta, China. Estuaries and Coasts 38:1885-97.

Zhang W-J, Xiao H-A, Tong C-L, Su Y-R, Xiang W, Huang D-Y, Syers JK, Wu J. 2008. Estimating organic carbon storage in temperate wetland profiles in Northeast China. Geoderma 146:311-316. https://www.sciencedirect.com/science/article/ pii/S0016706108001699?via\%3Dihub. Last accessed 26/08/ 2019.

Zheng YM, Niu ZG, Gong P, Dai YJ, Shangguan W. 2013. Preliminary estimation of the organic carbon pool in China's wetlands. Chinese Sci Bull 58:662-70. 